\title{
Toplumsal ve İnsani Boyutta İmkân ve İmtihan Alanı Olarak Aile
}

\author{
NEVZAT TARHAN
}

\section{Özet}

Makalede iyi eş, iyi anne, iyi baba olmadan önce iyi insan olmanın öneminden yola çıkılarak iyi aile olmak kavramına değinilecektir. İyi insan olmak için iyi aile ortamının gereğinden bahsedilecektir. Sonuç olarak, toplumsal huzur açısından iyi insan vasfının kaynağı olan aileyi bir arada tutan değerleri canlandırmaktan başka çarenin olmadığı vurgulanacaktır. Aile değerlerini ayakta tutmak, çocukları daha iyi yetiştirmek, eşler arası ilişki/iletişim kurmayı başarabilmek gibi becerileri kazanabilmek için doğal davranış eğitimi olan firsat eğitimine özellikle dikkat çekilecektir. Bu bağlamda toplumsal açıdan artık şikâyet aşamasında olunmadığı, kadim öğretilerimiz ile bilimsel verilerin ışığında çözüm zamanının ivedilikle yakalanması gereği salık verilecektir.

Anahtar kelimeler: evlilik, aile, çocuk, fursat eğitimi, değerler, örnek olma

\section{Abstract}

In this article the concept of a good family will be examined not based on being a good spouse or a good parent but based on being a good person. The necessity of a good family for becoming a good person will be discussed. As a result, the inevitability of reviving the values that hold the family together, which is the source of the good person, in order to achieve social peace will be expressed. The importance of the opportunity education as a natural behavioral education for preserving the family values, for raising children better, for acquiring better communication skills between parents et cetera will be mentioned. It will be advised that socially we shall no longer remain in a state of complaints and 
that we should use our ancient teachings and our scientific data to reach an immediate solution.

Keywords: marriage, family, child, opportunity of education, values, being role model

Psikiyatride önceleri üç alan önemsenmekteydi: Duygu, düşünce ve davranış. Artık iki alan daha önem kazanmıştır: Bedensel tepkiler ve değer sistemi. Bu bağlamda insanı analiz ederken insanın kendisiyle ilişkisi, mesleki ilişkisi, aile ilişkisi, evrenle ilişkisi ve varoluşsal ilişkisi bir bütün olarak ele alınmalıdır.

5N1K dediğimiz; "Kim, ne, nerede, nasıl, ne zaman, niçin" şebekelerinin insan beyninde kalıcı öğrenmeyi sağladığı bilinmektedir (Tarhan, 2014). Kadim kültürler bunu "ilim, hikmet ve marifet eğitimleri” ile vermişlerdir. Günümüzde de sinirbilimden yardım alarak fırsat eğitimi ile aynı etkiyi oluşturabilmek mümkündür. Beynin "ya kullan ya kaybet” prensibiyle çalışmasından hareketle beyni geliştirmeyi ve canlı tutmayı hedeflemek önemlidir.

Fırsat eğitimi, zamanı iyi kullanmak isteyen kültürlerde ve sistemlerde, özellikle işe yarayan bir eğitim biçimidir. Modern dünyada, egonun yükseldiği çağımızda insanlar didaktik usullere, ders gibi uygulamalara kendini kapatmaktadırlar. Bundan dolayı problem/çözüm odaklı eğitim ve fırsat eğitimi daha işe yarar olmakta; aynı zamanda insanları tekdüzelikten uzak tutarak sürekli yenilenme sağlayabilmektedir.

Erkek veya kadın evlenmeye karar verdiğinde, bir anlamda başka bir dünyaya karışmaya niyetlenir. Evlilikte kadın erkeğe ve erkek de kadına taşınır. Tabii ki kimse gittiği yere büsbütün dönüşmez çünkü kendini de gittiği yere götürür. Evlilik iki ayrı dünyanın birleşerek bir dünya oluşturmasıdır (Tarhan, 2014, s. 40). İnsan, evlilikte kalbine mukabil bir kalp bulmak ister. Zira insanda sevme, bağlanma, aidiyet duygusu vardır. Kişi, evlenmekle sevgisinin karşılığını bulur, duyguları öylece havada asılı kalmayıp somutlaşmış olur. Böylece kadın ve erkek, karşılık buldukları bir kalbe bağlanarak dünyada bir adres edinmiş olurlar (Tarhan, 2014, s. 40-41).

18

Çocuk ve Medeniyet 2021/1
Kişinin ve toplumun ahlaki değerlerinin gelişiminde evliliğin katkısı şüphe götürmez. İnsanın, her anlamda insan olarak doğduğu yer, ailedir. İnsan ve insanlık adına her şey ilk olarak ailede görülür, öğrenilir yani insan sahip olduğu ahlaki değerleri ilk aile ortamında pratiğe döker (Tarhan, 2014, s. 53). 
Ahlaki değerlerden kasıt nedir? Dürüst olmak, sözünde durmak, fedakârlık etmek vb. değerler. İnsan doğduğu yerde, öncelikle annesi babası üzerinden bu değerleri öğrenir. Bir adım sonrasında da öğrendiği değerleri, beraber olduğu aile fertleri ile uygulamaya başlar. Sosyalleşme bağlamında da ilk staj yeridir aile. Yani aile, sosyal olanın; toplumun en küçük örneğidir. Kendi dışında olanı tanıma, sınırları bilme, başkasıyla yaşama, başkasının sınırlarına saygı, farklılıkların bir arada olması/yaşayabilmesi, küçük çapta aile ortamında görülür, tecrübe edilir. İnsan, aile içinde sosyalleşir; başkasıyla yaşamayı, başkası için yaşayabilmeyi öğrenir. Kişi, ailede hem değerleri öğrenir hem bunları uygulama imkânı bulur. Dağda, inzivada ya da insanlardan uzak yerlerde insanın ahlakiliğinden bahsedilemez. Belki insan dışında diğer varlıklara karşı muamelede ahlakilik görülebilir ama ahlakiliğin insani boyutu ancak toplumda test edilebilir. Çelişkili, birbirinden çok farklı sesin oluşturduğu toplumda ahlaklı olabilmesi için kişinin, kendisini iyi bilmesi, ahlaki değerleri özümsemesi gerekir. Bu aile ile mümkündür; insan ailede kendini fark eder, ne yapması gerektiğini öğrenir (Tarhan, 2014, s. 53-55).

Erkek ve kadının gerçek hüviyeti; kişiliği, kimliği evlilikte ortaya çıkar. Çünkü insan ancak ilişkide kendinden dışarı çıkar; kendini göstermiş olur. Alışverişte, yolculukta insan içini gösterir. Ahlaklı mı değil mi, dürüst mü değil mi, bu ancak insani münasebet içinde belli olur.

Evlilik aynı zamanda insanın sınandığı yerdir. Kişinin doğduğu, kendisini gerçekleştirebildiği yer olduğu gibi test edildiği yerdir de yani bir imkân ve imtihan alanıdır aile. Hayat da böyle değil midir? Dünyaya doğan her kişi, insan olma imkânıyla doğar. Hayatta zorluk vardır, hareket vardır, çatışma, çelişki vardır. Bu çatışma ve hareketin ortasında insan, tercih etmek durumunda kalır. Neyi tercih ettiğine ve neden vazgeçtiğine göre hamurunda/tohumunda olan nitelikler gelişir. İyi olanı tercih eder ve kötü olana sırtını dönerse iyi insan olur, değilse aksi... Neticede her kişi insan olma imkânıyla doğarken herkes insan olarak ölemiyor. Çoğu kişi imkânları değerlendiremeyerek kaybediyor. Tıpkı toprağa atılan tohumlardan bir kısmının gün yüzüne çıkması gibi... Kimi tohumlar çürürken kimileri başak olup meyveye duruyor.

Hayat; diyalektik, çatışma ve hareket üzerine akışkandır. Aile ve evlilik ilişkileri de hayata benzer. Başta iki farklı insan bir araya gelir. Gece ile gündüzün bir araya gelmesi gibi... Kadın ve erkek, iki ayrı hikâye, iki ayrı dünya demektir. Bu iki ayrı dünyanın bir araya gelmesi, birleşmeye/ bir ve biz olmaya çalışmaları kolay olmaz. Evliliğe karar vermek, evlenmiş olmak demek değildir. Süreç içinde insanların gerçekten evlenip 
evlenmediklerine bakılır. Huzurlu ve mutlu evlilikler, kadın ve erkeğin sahiden evlenebildiklerine işarettir. Huzursuz, hep çatışmalı, boşanmanın kıyısında geçen evlilikler ise kadın ve erkeğin daha birleşmediklerini; biz olamadıklarını gösterir (Tarhan, 2014, s. 54-56).

Her kurumun olmazsa olmazı vardır; evliliğin olmazsa olmazı da sadakattir. Eşlerin birbirlerine ve varsa çocuklarına karşı sadakat ve sorumlulukları vardır. Toplumsal anlamda bakıldığında, aile oluşsun diye evlenilmektedir ve ahlaki normlar, aile kurumunda gerçekleşmektedir. Aile ise aileyi oluşturan fertlerin birlikte bir bütün oluşturmalarıdır. Fertlerin birbirlerine karşı değil birbirleri için olduğu hâller aileyi oluşturur. Durum bunun aksi ise yapılan evlilik, aileyi oluşturamamış demektir. Ailenin olmadığı yerde evliliğin sürdürülmesi ise genellikle daha büyük problemler doğurur.

Evlilikler ego savaşlarının yaşandığı yerler değildir, olmamalıdır; bir iktidar kavgası, intikamların alındığı bir arena olamaz. Evlilik, egoların biz potasında eritildiği, insanların kendisi için değil başkası için yaşadığı yerdir. Nefsin ve şahsın çıkarı değil, şahısların birlikte oluşturdukları ailenin menfaati önemlidir evlilik müessesinde.

Ailenin hukuku çiğneniyorsa şahıslara bakılmaz. Zira gemi batarsa yolcular da batar. Yolcuların selameti, geminin batmamasına bağlıdır. Aile; fedakârlığın, yardımın, iyiliğin, dürüstlügü̈n, dayanışmanın yaşandığı, göründüğü yerdir. Aile, aynı zamanda bütün bu değerler için vardır. Bunların olmadığı, bunlara karşı mücadelenin yapıldığı evlilikler artık aile olmaktan çıkmıştır, dolayısıyla bitirilmesi daha hayırlıdır. En azından kötü örnek olmaktan çıkarlar. Zira kişiler bu evliliklere bakarak evlenmekten korkmakta, evlenmekten vazgeçmektedirler. (Tarhan, 2014, s. 58)

İki ayrı insanın, iki cinsin bir araya gelmesi sebebiyle tabii ki evlilik öyle problemsiz, toz pembe bir hayat sayfası değildir. Evliliğin merkezinde insan vardır. İnsan ise hem nefisten hem de ruhtan oluşur. Kötü ve iyi olanın mücadele sahası olan iki insanın bir araya gelmesi meseleyi daha da çetin kılar.

Kadın ve erkek yani kendi içlerinde zaten insan olabilme mücadelesi yaşayan iki insan bir araya gelir; bu birliktelikle kadın ve erkeklik hâlleri de yaşama dâhil olur. Hem erkek hem kadın, başta insan olmaktan kaynaklanan bir mücadele yaşarlarken evlilikle birlikte cinsiyetlerin farklılığından kaynaklı problemlerle başa çıkmak durumunda kalırlar. Böylece evlilik

Çocuk ve Medeniyet 2021/1 birçok farklılığın devreye girdiği bir şey olur. Bu da yetmez, ülkenin sosyoekonomik durumları da buna dâhil olur ve evlilik, aile olmak o kadar zorlaşır ki! Böylesi durumu taşımak, buradan ahenkli bir birliktelik oluşturmak 
büyük çaba gerektirir. Hem kadının hem erkeğin bu meselenin altından kalkmak adına ciddi bir donanım edinmeleri şart olur. İlk yapacakları şey, şahsi düşünmemeleridir. Sadece kendi çıkarını düşünmek, yanındaki eşini düşünmeden hareket etmek, çok basit ve yanlıştır; bencilcedir.

Kişiler, güzel ve çirkinin toplamı bir varlık olduklarını bilmek durumundadırlar. Kendilerindeki çirkini bastırıp güzeli açığa çıkarmak için eğitimler almalı, bu istikamette yoğun bir okuma içinde olmalıdırlar. İlk önce nefisleriyle mücadele etmeli, kalp ve ruhlarını diri kılmalıdırlar. Kalp ve ruhu açığa çıkmış, vicdanı dirilmiş insan, ilişkide çıkan problemde başta kendi hatasını görmeye çalışır, kendini düzeltmeye bakar. Bu yapıldığında, ilişkinin karşı tarafında yer alan insan düşünmeye, hatasını görmeye başlar.

Tarafların sadece birbirlerini eleştirdiği hâller konuşma sayılmaz, bunlar ego savaşının yürütülmesidir. Bu ise evliliği bitiren bir şeydir. Eleştiri, hakikati itibariyle başkasını büsbütün öldürme değil, hakikatin ortaya çıkmasına yarayan bir yöntemdir. Ama eleştiri, her an silaha dönüşebilir, dolayısıyla bu konuda hassasiyet şarttır. İncitmeden, kırmadan, hatanın ortaya konulması gerekir. Olumlu ve olumsuz eleştiri diye bir şey vardır. Evlilikte kişiler başta kendilerini görmeli, nerede ve nasıl hata ettiklerini rahatlıkla ortaya koyabilmelidirler. Kendini eleştirmeden karşı tarafı eleştirmeye girişmemelidirler. Kişiler hem eleştiriye açı olmalı hem eşinin özgürlüğüne saygı duymalıdır. Eşini konuşturmamak, kendini ona dayatmak büyük bir haksızlıktır. Birbirine saygının olmadığı yerde, birbirini sevme de olmaz. Unutulmamalıdır ki insan, ancak saygı duyduğunu gerçekten sevebilir (Tarhan, 2014, s. 60-61).

İnsan, hayat arkadaşının olmasıyla ve kalbine karşılık bir kalbin bulunmasıyla, psikolojik ihtiyaçlarının büyük kısmına karşılık bulur. Evliliğin temelinde bu ihtiyacın karşılanması vardır. Evlilikte arkadaşlık ve dostluk boyutu var; hayatı paylaşma boyutu var; anne ve baba olma boyutu var. İnsan, evlilik sayesinde arkadaş, dost, anne ve baba olabilmektedir.

Toplum; mekân ve insan, değerlerle kurulur ve böylelikle varlığını sürdürebilir. İnsan, değer demektir; “değer”siz bir varlığa çok da insan denemez, böylesi bir varlık sadece biyoloji ve beden olarak değerlendirilebilir. İki insanın bir araya gelmesi, ilişki içinde olması ise değerler sayesindedir. İki insanı da aşan değerler olmayınca şahsi çıkarlar, nefsanî arzular ortaya çıkar ve bütünüyle hayatı kaplar ki bu, münasebetleri bitiren bir şeydir (Tarhan, 2014, s. 85).

Nedir insanı insan yapan kişilik değerleri? Temel değerleri, amaç ve araç değerler olarak sınıflandırdığımızda değerlerin hayata geçirilmesinde 
araç değerlerin, en az amaç değerler kadar doğru olması gerekmektedir. İnsanların isteklerini/hedeflerini amaçlar, taleplerin niteliğini ve hayattaki yolunu ise araçlar belirlemektedir. Benimsenen insani evrensel değerlerin hayata geçirilmesini sağlayan araç değerler, insan için motivasyonu sağlamakta ve teşvik edici olmaktadır (Tarhan, 2019, 21-22; 2014, s. 85). Kadimden bu yana insanlığın temel değerleri şöyle sıralanabilir: Dürüstlük ve şeffaflık, adalet, cesaret, iyimserlik, ümit, gayret, başkasının sınır ve haklarına saygılı olmak, sorumluluk, sadakat, erdem, hikmet, mahremiyet algısı, verilen sözde durmak, karşıdakine değer vermek, takdir etmek, alçakgönüllü olmak, iyi niyet taşımak, emeğe saygı göstermek, yardımlaşma, selamlaşma, helalleşme, içtenlik, samimiyet, affetmek, bağışlama, cömertlik, şefkat, fedakârlık, şükür, kanaat, barış, paylaşma, hoşgörü, uzlaşma, çoğulculuk, katılımcılık, özgürlükçülük, özeleştiri, kendini geliştirmek, çalışmak, vicdan...

Değerler, farklı kültür ve dinlerde farklı boyutlarda önemsense de insan beyninde değerlerin temelini oluşturan iki unsur dikkati çeker: İyiliğe yönelmek ve kötülü̈̆ge yatkınlık. İnsan denen varlığın hayatının doğru biçimde devam edebilmesi için denge kurmayı başarması gerekmektedir. Kültüre özgü değerler, evrensel değerlerin çeşitli ölçülerde karışmasıyla oluşur (Tarhan, 2019, s. 23). Bütün bu değerlerin mayasında ise sevgi vardır. Modern dünyada sosyal ve duygusal beyin/sinirbilim çalışmaları ile ahlakın ve duyguların fiziksel kanıtlarına sahibiz. Değerlerin psikolojik dinamiği ve yerinde kullanılmasının koruyucu ruh sağlığı ve toplum ruh sağlığı açısından önemi yadsınamaz. Değer başkasına ne yaptığımızla ilgili bir şey ise, başkasına "iyi” davranmak başlığı altında toplanıyorsa, bu başkasını sevmeyi gerektirir. Dolayısıyla sevgi, hayatın mayası ve ruhudur. Sevgiyle beslenen değerlerin hem kişiler hem de toplum tarafından kolayca benimsendiği bilinmektedir. Bir kimsenin bir değerin rol modeli/örnek insanı olması; o değeri hatırlatan davranışları ve sözleriyle mümkündür.

Sevginin mayaladığı değerlere sahip kişi, temelde iyi olana taliptir, iyi olanı ister. Bunun için bakar, düşünür, çalışır, bu istikamette yürür. Bu kişiler, iyilik ve nitelik için başkasına gider, evliliği bunun için yapar, bu maksatla ilişki kurar. Kendini iyileştirmek ve güzelleştirmek üzere giderken, gittiği kişide de iyi olanın olmasını, yansımasını ister.

Kişi, evlendiği kişiye karşı iyi davranır, iyi davrandığında iyiliğe sebep olur. İyi insanların evliliği ve ilişkileri de iyi olanın yetiştiği birer merkez olur. $\mathrm{Bu}$

Sevgi birçok kapıyı açan bir anahtardır; kişileri birbirine bağlayan mıknatıstır. Bir ailede sevgi varsa yani bir aileyi sevgi kurmuşsa, o ailenin 
fertleri arasında görünmez ve kopmaz bağlar vardır. Binayı oluşturan tuğlalar düşünüldüğünde arada bir harç vardır ve bu harç onları birbirine bağlar. Esen rüzgâr, yağan yağmur binayı yıkamaz. Böylelikle binanın içindekiler dışarıdan korunur. Sevgi de aile fertlerini birbirine bağlayan, onları bir arada tutan harç gibidir. Kendi başlarına ayrı birer insan olan fertler sevgiyle bağlanır; bir insan, bir aile olurlar. Aradaki bu görünmez bağ üzerinden birbirlerine akarlar (Tarhan, 2014, s. 87).

Aile çıkara ve sadece hazza bağlı olmayan bir sevgiyle kurulmalı; böyle bir sevgi üzerinde temellendirilmeli. Bir taraftan da var olan bu sevgi geliştirilmeli, içi hep iyi şeylerle doldurulmalıdır.

Anne ve baba, çocuklarını iyi çocuklar olduğu için değil çocukları olduğu için sevmelidir. Yani şartlı, taahhütlü, koşullu bir sevgi değil yaratılmış olmaya ve emanet olmaya dayalı bir sevgi. Çocuklar farklı şeyler söyleyebilir, anne ve babanınkine benzer olmayan düşüncelere sahip olabilirler. Böyle oldukları için sevilmezlerse anne ve baba bencil davranıyor demektir. Şartlı sevgi, sağlıklı bir sevgi değildir. Karşılıksız, beklentisiz sevilmelidirler ki çocuklar da anne ve babalarını hesapsız sevebilsinler. İdeal sevgi, şartsız sevgidir. Bunun adı da şefkattir. Şefkat, koşulsuz sevginin adıdır. Şefkatte karşılık beklenmez (Tarhan, 2014, s. 88-89).

Hakiki sevginin dilleri vardır. Bu dilleri bilmek gerekir. Bu dilleri bilmeden insan sevgiyi gösteremez. Sevginin aktığı kanallar vardır, bu kanallara sahip olmak gerekir.

Sevginin kendini gösterdiği kanallardan, dillerden biri hediyeleşmedir. Hediyeleşme bizim toplumda yaygın olan bir şeydir. Özel günler hediyeleşme için birer sebeptir. Özel günlerde verilen hediyeler aradaki sevgiyi gösterir ve çoğaltır.

Sevginin en güzel ifadelerinden biri de fedakârlıktır. Sevdiği kişi için rahatından, parasından vazgeçmek ya da sevdiği için bir şeyler yapmak... Sabah eşi yatarken kalkıp ona kahvaltı hazırlamak, rahatsız olduğunda kendisine küçük ilaçlar hazırlamak, ateşlendiğinde başında beklemek, onun yaptığı vazifelere refaket etmek gibi.

Sevginin diğer ifadelerinden biri de, eşlerin birbirlerinin ihtiyaçlarını bilmesidir. Eşi neyi seviyor, nelerin yapılmasını arzu ediyor? Bu sorunun cevabını bilen, istenmeden bunları yapan kişi seviyor demektir. Böylesi bir durumda eş, "eşim beni seviyor çünkü benim beklentilerimi biliyor" der. Eşlerin birbirlerini bilmesi ve tanıması için beraber vakit geçirmeleri lazımdir. 
Konuşmak, konuşabilmek de sevginin dillerindendir. Konuşuyorsa, sohbet ediyorsa seviyor demektir, seviyorsa konuşur. Konuşmak, özellikle konuşmalarda birbirlerini övme... Eş, eşinin güzelliklerini sayarak onu onurlandırmış olur. Konuşma olmazsa takdir de olmaz, övgünün olabilmesi için konuşmak gerekir. Konuşan, öven, takdir eden kişi, eşini ruhen okşamış sayılir.

Fiziksel temas ise, sevginin en ortada olan dilidir. İnsan sevdiğine dokunmak, sarılmak ister. Bir göz teması, omuza dokunma, saç okşayışı, tebessüm vb. fiziksel temas olarak değerlendirilir.

Bu diller kullanıldığında sevgi kendini göstermiş olur, görünen sevgi, muhteşem bir beraberliğe zemin olur. Nitelikli beraberlik kurulmuşsa sevgi de o yuvada varlığını sürdürür (Tarhan, 2014, s. 89-91).

Saygı hâlinde de kişi hem kendini hem de başkasını görür. Bu, hem kendinin hem de başkasının sorumluluklarını bilmesi anlamına gelir. İnsan sosyal bir varlıktır. Saygı, birinin varlığını görmek ve ona hürmet etmek demektir; kendine gösterdiği ihtimamı yanındakine de göstermektir. Saygıda kişi kendini gördüğü gibi başkasını da görür. Saygı formunda kişi haddini bilir, sınırlarını geçmez; başkasını bilir, onun sınırlarından izinsiz içeri girmeyi kendine hak bilmez. Birine saygı duyulması, onun sayılması, görülüp fark edilmesidir. Görülen, görüldüğü şekliyle var sayılan saygı görüyordur. En büyük ceza kişinin görülmemesi, yok sayılmasıdır. Saygı, psikolojide ilişki sınırlarının bilinmesi şeklinde algılanır. Duvarlar nasıl evleri birbirinden ayıran sınırlar ise, insanlar arası saygı da buna benzer görünmez sınırlar anlamina gelir.

Her insan özeldir, mahremiyete sahiptir. Bir irade olarak beliren her insan, saygıyı hak eder. İradesiyle görünmeyen, görünmesine müsaade edilmeyen, saygı duyulmayan insan yok sayılıyor, öldürülüyor demektir. İnsanı öldürmek her zaman biyolojisine son vermek şeklinde anlaşılmamalı, onun iradesini yok saymak ve iradesine engel olmak da onu öldürmektir.

Bir de insanın iç yasaları vardır; ahlak ve değer, helal ve haram gibi... İnsan ahlaki değerlere, haram ve helal ölçülerine uygun davrandığında iç sorumluluklarını yerine getirmiş olur. İç sorumluluklarına ters düşmüş kişiyi vicdanı hesaba çeker, kişi suçlu olduğunu bilir, vicdan azabı çekmeye başlar. Vicdanı diri olanlar, iç sorumluluklarının bilincine uygun davranır. Vicdanı diri insan hem dış hem de iç sorumluluklarını yerine getirmeye çalışır, mutluluk ve huzuru böyle yaşamakta görür.

Çocuk ve Medeniyet 2021/1
Evlilik ve aile, saygı için hem sebep hem de sonuçtur. Saygın nesiller için evlilik ve aile lazım olduğu gibi sahih ve sağlıklı ailelerin devamı da saygılı kişilere bağlıdır. 
Evlilikte saygı; erkek ve kadının, karı ve kocanın birbirlerini kabulü demektir. Erkek, eşi olan kadının varlığını kabullenecek, onun sınırlarını ihlal etmeyecek. Kadın da eşi olan erkekten kendine teslim olmasını istemeyecektir. Birbirlerinin eşi olabilirler ama birbirlerinin esiri değillerdir. Bunun farkında olan çiftler, kendilerinden vazgeçmeden ortak bir yerde buluşmaya çaba göstereceklerdir.

Kadının görülmediği veya erkeğin devreden çıkarıldığı evliliklerde adalet zarar görür. Adaletli evlilik, kadın ve erkeğin birlikte katıldığı bir müessesedir; kadın ve erkek, böylesi evlilikte hakları çiğnenmeden yaşar.

Evrende, varlıkta adalet ve merhamet dengesi çok önemlidir. Merhamet, sevgi ve saygının hissedilmesine işaret iken; adalet, bunun sınırları içinde yapılması demektir. Evlilikte eşe ve çocuklara karşı sevgi ve saygı esastır, ancak bunun sınırlarını da bilmek gerekir.

Ahlak; "doğru ve iyi olanı, doğru ve iyi nedene bağlı olarak, doğru ve iyi bir şekilde yapmak" şeklinde tanımlanır. Çocuğa ahlak eğitimi en doğru şekilde rol model yani örnek olunarak verilir. Ebeveynin hayata ve olaylara bakışındaki incelik, problemler için düşündükleri çözümlerin ahlaki kriterlere uygunluğu, çocuğun ahlaki eğitimi için en temel bileşenlerdir. Çocuk doğumdan itibaren ilk yaşlarda gördüğü örnekler üzerinden bir hayat kılavuzu edinmiş olur. Sonraki öğrenmeleri, bu ilk yaşlardaki temelin üzerine bina edilir. Aile ve ev ortamı (ya da mecburiyetler karşısında bakım verilen ortamlar); iyi ve kötü insan yetiştiren laboratuvarlar gibidir. Bundan dolayıdır ki aileye yatırım, evlilik kurumu ve toplum açısından çok önemlidir.

Çocuklara küçük yaşlardan itibaren verdiğimiz karakter eğitimi aslında ahlaki değerlerin eyleme dönüşmüş şeklidir. İnsanın çocukluğunda öğrendiği değerler, beyne program gibi yazılmış olur. Bazı değerler sabittir ve basit doğrular insanı mutlu eder, güvende hissettirir. Değerlerin özünü değiştirmeden yenilenmesi tıpkı yaşayan dil gibi imkân dâhilindedir. İnsan, çocukluktan itibaren öğrendiği değerleri, başka kişilerle bir araya geldikçe ve yeni şeyler öğrendikçe günceller ve yeniden şekillendirir. İnsan, hayat becerilerini geliştirdiği ölçüde değerleri özümseyecek ve kişiliğini geliştirecek, olgunlaşabilecektir. Kişiliğin ve karakterin gelişmesi de davranış diline yansıyacaktır.

Sorumluluk duygusunun kişinin kendine bakan yönüne, iç denetim sistemine, psikolojide internal stopper yani iç durdurucu; yasalar, toplum,

Çocuk ve Medeniyet 2021/1 anne, baba gibi dışarıdan gelen kural koyuculara ise external stopper yani diş durdurucu denmektedir. Psikolojide iç durdurucu diye bahsedilen mekanizma aslında iç disiplin olarak da bilinen vicdan mekanizmasıdır. 
Vicdan mekanizması çalışmayan, iç denetim sistemi öğretilmemiş çocuğun kendisi dışındaki herkesi engel gibi görmesi, en ufak bir hayıra bile tahammül edememesi, bir engelle karşılaştığında karşısındaki insanı öldürmeyi bile düşünebilecek seviyeye gelebilmesi maalesef mümkün olabilmektedir. Çocukta doğru çalışan bir vicdan (iç denetim/iç engelleyici/ iç durdurucu vb.) mekanizması geliştirebilme sorumluluğu, aile ortamında öncelikle ebeveyne (ya da mecburi durumlarda bakım verene) aittir. Bu noktada da dengeyi tutturmak önemlidir zira eğer çocuğun vicdanı üzerinde fazla baskı kurulursa süperegonun yanlış gelişmesine sebep olmaktadır ve toplumumuzda en çok yapılan hatalardan biridir. Böylesi, çocukta suçluluk duygusu uyandıran ya da rekabeti pekiştiren bir eğitime dönüşmektedir. Çocuğun kardeş kıskançlığı yaşadığı durumda "Nasıl böyle düşünürsün?" tepkisi de "Zaten ben de onu çok sevmiyorum." tepkisi de yanlıştır. İki durum da çocukta çelişkinin oluşmasına neden olacaktır. Oysa böyle bir durumda anne babalar, "Kardeşini çok sevdiğimizi mi düşünüyorsun? Biz onu da seni de çok seviyoruz." dediklerinde, çocuk anlaşıldığını, duygularının görmezden gelinmediğini ama kaygı duyması gereken de bir durum olmadığını anlayacak ve rahatlayacak hem de duygularını bastırmak gibi bir yöntemi de öğrenmemiş olacaktır. Bu tarz yaklaşımlarla duygularını tanıyan, onların farkına varan ve gereği gibi ifade edebilen bir çocuk yetişecek ve duygularıyla baş etme becerisi kazanacaktır. Vicdan eğitimi, gerekli durumlarda insanın içgüdülerine direnç göstermesini sağlar. Vicdan, insanın iç düzenleyicisi ve denetimcisidir.

İnsanın istek ve dürtüleri ile yaptığı mücadele ve eğitim çalışması, temel yaşam becerisini oluşturur. Kendine zarar verici, yıkıcı, riskli sonuçları olan dürtüleri kontrol altına alabilmek ve şefkatli olmak için geliştirilen duygusal alışkanlıklar, sosyal beceriler edinilmesi gerekir. Goleman'ın da vurguladığı gibi “İki ahlaki tavra ihtiyacımız var: Kendine hâkim olmak ve şefkat göstermek” (1998, s.11). Dürtüsüzlük insanı, acizliğe, tembelliğe, yalnızlığa iterken dürtülerin aşırı ifade edilmesi de acımasızlığa, başkalarına kötülük yapmaya, aceleciliğe, sabırsızlığa, ahlaksızlık olarak nitelendirilen davranışlara itebilmektedir. Dolayısıyla hem bedensel hem de psikolojik olarak dengeli insan olabilmek, davranışlara da dengeyi yansıtabilmek hem kişisel huzur hem de toplumsal huzur açısından önemlidir. Genetik mirasımızın bize bağışladığı duygusal eğilimlerin yine bu konudaki eğitimlerle, egzersizlerle beyinde duygu devreleri hâline dönüşmesi, hislerin eğitimi ya da atalarımızın ifadesiyle nefis terbiyesi olarak nitelendirilir.

Çocuk ve Medeniyet 2021/1
Kendini tanımak, kendini denetlemek, empati, özgecilik/diğerkâmlık, anlaşmazlıkları çözme, uzlaşma, iş birliği yapma vb. insani becerilerin öğrenilmesi; akıl ve kalbin birleştirilerek eğitilmesini gerektirir. İnsanı insan 
yapan unsurun, beyinle duygular arasındaki ilişkiyi iyi kullanabilmesi ve yönetebilmesi olduğunu söylemek yanlış olmayacaktır. Batı'da terk edilen ya da kaybedilen manevi değerlerin, modern yaşamın kazanımlarını koruyarak tekrar hayata geçirilmesi psikoloji ile sağlanmaktadır: Duygusal zekâ kavramı, pozitif psikoloji kavramı, öğrenilmiş iyimserlik vb. kavramlar.

Ailede ve toplumda çocuklardan kırk yaşındaki insanın olgunluğu beklenilmemelidir. Bu hem mantıklı hem de insani değildir. Çocuktan bunu beklemek çocukla empati kurmamak demektir. Duygusal sağırlık olarak tarif edilen empati yoksunluğu egoizmin, bencilliğin ve kibrin sonucudur. Çocuk, temel güven duygusu oluştukça bireyselleşir ve kendi kişiliğini kazanmaya başlar. Temel güven duygusunun oluşması için çocuğun tutarlı, yeterli, kararlı ve devamlı bir ilişki kurması gerekir özellikle de annesiyle (ya da zaruri durumlarda anne yerine geçen kişiyle). Bu duygunun biçimlenmesinde çocuğun yaşadığı çevrenin ve çevresindeki kişilerin tutumları belirleyici rol oynar. İç gelişimi göz önünde bulundurulan; yetiştirilmesi sırasında iyi olduğu konularda desteklenen, takdir edilen çocuk/kişi, o konuda/konularda ustalaşır. İdeal olan, çocuğu cesaretlendirip süreci kendisinin başarmasını sağlamaktır; rehberlik edip, yol açıcı olabilmek... Çocuk, varlığına önem verildiğini, sevildiğini, desteklendiğini hissedebilir ve yaşayabilirse temel güven duygusu pekişir. Olumlu benlik algısının oluşturulabilmesi, kişinin kendisiyle barışık olmasını sağlayacaktır. Kişisel güven duygusunun pekişmesi, bunun aileye ve dolayısıyla topluma yayılmasını sağlayacak ve kolaylaştıracaktır. Bu da savaşçı, rekabetçi bir ortamı değil huzurlu bir ortamı beraberinde getirecektir. Yetiştirilme tarzları ve aldıkları eğitim sonucunda kişisel kapasitelerinin farkına varan çocuklar, erişkinliklerinde problemlerini çözebilen, doğru kararlar alabilen, kişiliği oturmuş insanlar olarak kendi hayatlarını sürdürebilecek hem de topluma olumlu katkıları olacaktır.

Aklıyla fırsatları fark etme ve kullanma becerisi olan, tecrübelere açık, sorgulayan, olaylara tutucu bakmayan, olumlu düşünmeye yatkın, bir olayla karşılaşıldığında verilen ilk tepkinin olayı güzel tarafından ele alan, ümitsizliğe düşmeyen, sezgilerine önem veren, risk alabilen, eleştiriyi tehdit olarak algılamayan, tam bir motivasyonla hayata sarılan, engellere tahammül edebilen kişilerin hayatta şanslı sayılan grupta yer aldığına dair çalışmalar dikkat çekmektedir. Düşüncelere duygu katabilmek yani duygusal mantıkla davranabilmek; stratejik düşünme yeteneği, hayat başarısı için gereklidir. İnsanın iç eğitim ve öz terbiye ile davranış zekâsı oluşturması; iyi kişilik özelliklerine sahip olması; belli düşünce, duygu ve davranış kalıplarını adeta kimyasal harflerle beynine yazması ve bunu tekrar ederek pekiştirmesi ile mümkündür. Tabii ki bu kolay bir şey değildir, çaba gerektirir ve değerler, 
insanın davranışlarında çok belirleyicidir. Kişinin duygularını fark etmesi, doğru değerler seçmesi ve iyi davranışlarda bulunması birbirini izleyen basamaklardır.

Çocukların empatik, ilgili ve sorumluluk sahibi olması istenirken bunun, çocuğun yaşına, cinsiyetine, gelişim düzeyine uygun beklentilerle mümkün olduğu dikkatten kaçırılmamalıdır. Bununla birlikte insanlara empati yeteneği kazandırmanın, şefkati geliştirmenin, iyi insan olmayı öğretmenin en doğru zamanı, çocukluk çağlarıdır. Hayatın ilk yıllarında öğrenilen duygusal empati, sonraki yıllarda gelişerek zihinsel ve soyut empatiye daha kolay bir şekilde dönüşebilmektedir. Aileden gördükleri, duydukları ile çocuk, sevgiyi, empatiyi, yardımlaşmayı vd. becerileri/değerleri öğrenir. Mesela çocuğa diğer erdemlerin/değerlerin üzerinde geliştiği sabrı öğretmenin en iyi yolu, annenin babanın olaylar karşısında aktif sabır sergilemesi ve çocuğun da buna şahit olmasıdır. Yoksa çocuğa "Sabırlı ol!" demek ve sürekli öğütte bulunmak ile sabır öğretilemez ve bu lafta kalan öğütler davranışa dönüşemez. Hakiki manada aktif sabrın göstergesi, tahammülü tembelliğe dönüştürmeden hareket hâlinde beklemeyi bilmektir. Sabır (ve kadere iman) noktasında sağlıklı bir ruh sağlığı için insanın, kurallara uyup gayret gösterdikten sonra sonucun kendisi açısından iyi olduğunu kabullenmesi gerekir.

Sonuç olarak, sosyal ve duygusal beceri kazandırma noktasında da çocukluktan itibaren aile ortamının, çocuğun çevresini oluşturan kişilerin olumlu rol modeller olmasının öneminin farkında olarak ve insan olmanın ölçütlerini dikkate alarak, beraber yaşama bilinci oluşturmaya yönelik yönlendirici, yol gösterici, bilgilendirici eğitimler, uygulamalı çalışmalar arttırılmalıdır. Çocuklara her anlamda ve hayatın her aşamasında ama özellikle ailede doğru modeller sunulmalıdır.

Brighause ve Swift'e göre (2014), aile değerleri ${ }^{1}$, ebeveyn-çocuk ilişkisinin etik standartları demektir. Birimleri bir arada tutan değerler varsa sistem bir arada canlı kalır; değerler yok olursa görünmeyen bağlar da yok olduğu için yapı dağılır. Ortak kültürü, ortak idealleri ve ortak tarihi kuvvetli olan bir millet olumsuz dış etkenlere karşı güçlü olur. Bir ailenin de ortak bağları ne kadar güçlü ise zorluklara, maddi manevi güçlüklere karşı o kadar dayanıklı olur. Böylece aile fertleri, birlikte olumsuz durumların üstesinden gelebilir; olumlu durumları, iyilik hâlini çoğaltır; güçlenerek anda kalabilir ve geleceğe ulaşır.

1 Aileyi bir arada tutan başlıca değerler: Sevgi (love, affection), saygı (respect, esteem), güven (trusting, confidence), paylaşımcılık (sharing), meşveret (conferring), eşitlik (equality), özerklik (auotonomy), hakkaniyet (justifying), maddi kazanımlar (secular upbringings), manevi kazanımlar (religious upbringings). 


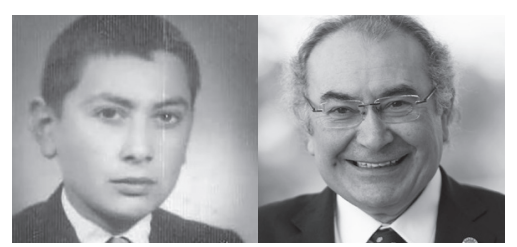

\section{Nevzat Tarhan}

\section{Kaynakça}

Baron-Chen, S. (2012). The Science of Evil on Empathy and the Origins of Cruelty. New York: Basic Books.

Brighouse, H., Swift, A. (2014). Family Values The Ethics of Parent- Child Relationships. Princeton Oxford: Princeton University Press.

Brisch, K. H. (2011). Treating Aftachment Disorders, From Theary to Therapy. New York, London: The Guil Ford Press.

Can, S. (2001). Cevahir-i Mesneviye. İstanbul: Ötüken Yayınları.

Gardner, H., Davis. (2013). The App Generation. New Haven and London: Yale University Press.

Goleman, D. (1998). Duygusal Zekâ Neden IQ'dan Önemlidir. İstanbul: Varlık Yayınları.

Goleman, D. (2005). Yıkıcı Duygular İle Nası Bașa Çıkabiliriz? Dalai Lama İle Yapılan Bilimsel Bir Diyalog. İstanbul: İnkılap Yayınları.

Gottman J. M., Katz L. F., Hoovan, C. (1997). Meta Emotion: How Families Communicate Emotinally. Lawrence Erlbaum Associates.

Mc Ginnis, Alan L. (1999). Sevginin Gücü. İstanbul: Beyaz Yayınları.

Kotin, Joel M.D. (2001). Eșinizi Etkileyerek Evliliḡinizi Kurtarın. İstanbul: Timaș.

Ryan Aho, S. (1996). Annelerden Dersler. HYB.

Shapiro, Lawrence E. (2000). Yüksek EQ'lu Bir Çocuk Yetiștirmek. İstanbul: Varlık Yayınları.

Tarhan, N. (2010). Güzel İnsan Modeli. İstanbul: Timaș.

Tarhan, N. (2014). Bilinçli Aile Olmak. İstanbul: Timaș.

Tarhan, N. (2017). Toplum Psikolojisi ve Empati. İstanbul: Timaș.

Tarhan, N. (2019). Deḡerler Psikolojisi ve İnsan. İstanbul: Timaș.

Tarhan, N. (2019). Duyguların Psikolojisi. İstanbul: Timas.

Tarhan, N. (2019). Mutlu Evlilik Psikolojisi. İstanbul: Timaș.

Weishaar, M. E., Klosko J. S. (2009). Sema Terapi. İstanbul: Litera. 


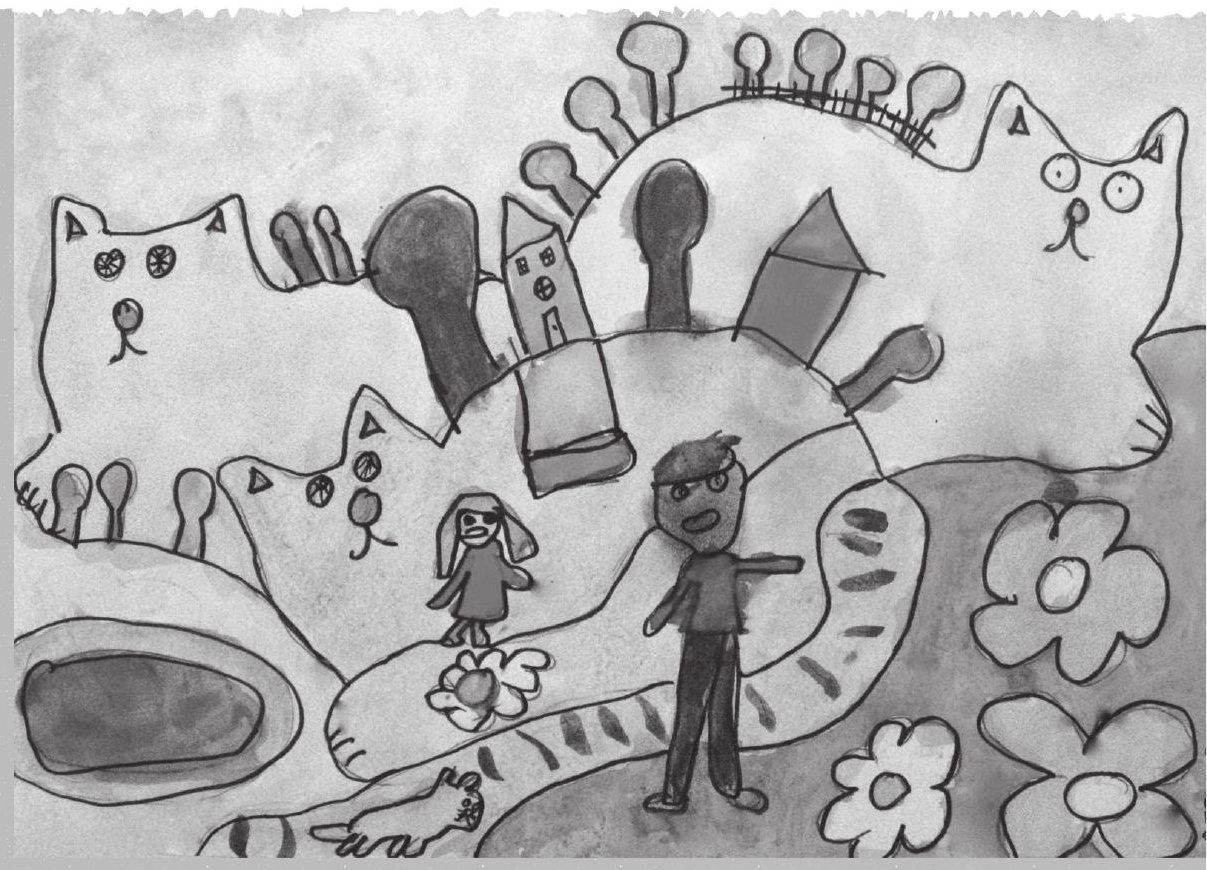

